\title{
PEMANFAATAN FITUR REFERENCE MS-WORD UNTUK EFISIENSI MANAJEMEN NASKAH LAPORAN DAN ARTIKEL ILMIAH UNTUK SISWA/I SMK
}

\section{$M S$-WORD REFERENCE FEATURES FOR MANAGEMENT EFFICIENCY OF REPORT MANAGEMENT AND SCIENTIFIC ARTICLES FOR VOCATIONAL SCHOOL STUDENTS}

\author{
Rudi Santoso*1, Achmad Yanu Alif Fianto ${ }^{2}$ \\ ${ }^{1,2}$ Fakultas Ekonomi dan Bisnis Universitas Dinamika \\ *e-mail: rudis@dinamika.ac.id
}

\begin{abstract}
The skills of office administration staff are not just conventional competences. However, they must also have digital knowledge and competence, especially in managing manuscripts. This competence must be built in school, especially in vocational schools. SMK Dharma Siswa 2 Sidoarjo is one of the organizers of a vocational school that produces graduates with job-ready competencies. The problem faced by these vocational high school students is mastery of office applications, especially MS-Word, especially optimization of application features. This training aims to improve the competence of these SMK students in mastering the MS-Word application by optimizing the use of features that are rarely used. This training provides knowledge about the use of references for efficient management of scientific manuscripts and articles. The training results showed a significant improvement. Participants' literacy increased from level 2 to level 6 on a scale of 1-10 in the use of the feature.
\end{abstract}

Keywords: MS-Word, MS-Office, Reference, SMK

abstrak

Ketrampilan tenaga administrasi perkantoran bukan hanya kompetensi konvensional. Namun juga harus mempunyai bekal pengetahuan dan kompetensi digital, terutama dalam pengelolaan naskah. Kompetensi ini harus dibangun sejak di bangku sekolah khususnya sekolah kejuruan. SMK Dharma Siswa 2 Sidoarjo adalah salah satu penyelenggara sekolah kejuruan yang menghasilkan lulusan dengan kompetensi siap kerja. Permasalahan yang dihadapi siswa/i SMK tersebut adalah penguasaan aplikasi office khususnya MSWord terutama optimalisasi fitur aplikasi. Pelatihan ini bertujuan untuk meningkatkan kompetensi siswa/i SMK tersebut dalam hal penguasaan aplikasi MS-Word dengan mengoptimalkan penggunaan fitur yang jarang digunakan. Pelatihan ini memberikan pengetahuan tentang penggunaan referen untuk efisiensi manajemen naskah dan artikel ilmiah. Hasil pelatihan menunjukkan peningkatan yang signifikan. Literasi peserta meningkat dari level 2 ke level 6 pada skala 1-10 dalam penggunaan fitur tersebut.

Kata kunci: MS-Word, MS-Office, Referen, SMK

10.20473/jlm.v5i1.2021.130-139

Open acces under CC BY-SA license

Creative Commons Attribution-ShareAlike 4.0 International License

\section{PENDAHULUAN}

Masa pandemi Covid-19 memaksa sebagian tenaga administrasi dan lainnya harus bekerja dari rumah. Kondisi masa pandemi tidak menyurutkan tenaga administrasi untuk tetap bekerja mendukung kinerja perusahaan. Kompetensi kerja dari rumah yang didukung oleh aplikasi office ini tentu saja harus ditempa sejak dini di bangku sekolah. Kegiatan yang dilakukan oleh (Salam and Iqbal 2020; Sormin, Sahara, and Agustina 2018) menunjukkan peningkatan profesionalisme masyarakat dengan membekali kemampuan penguasaan office. Sosialisasi dan pemanfaatan fitur tersembunyi yang jarang digunakan oleh tenaga administrasi mampu meningkatkan efisiensi dan 
produktivitas kinerja tenaga administrasi. Hal ini senada dengan penelitian yang dilakukan oleh (Valentina, Maisyaroh, and Kusumaningrum 2018), di mana dalam penelitiannya ditemukan ada hubungan kompetensi kerja dan motivasi terhadap kinerja tenaga administrasi.

Kompetensi tenaga administrasi bukan saja dibekali dengan ketrampilan yang konvensional. Namun lebih dari itu, penguasaan TI sebagai tools (alat kerja) utama menjadi pendorong peningkatan kinerja tenaga administrasi (Perdana 2019). Penguasaan ini tidak diperoleh dengan instan, namun melalui proses yang panjang. Paling tidak proses tersebut diawali di bangku sekolah menengah kejuruan. Salah satu output yang ingin dicapai oleh sekolah kejuruan adalah mencetak tenaga yang terampil di bidang masing-masing. Kompetensi administrasi perkantoran adalah salah satu luaran yang ingin dicapai oleh Sekolah Kejuruan. Sekolah Menengah Kejuruan menjadi penting manakala sekolah kejuruan diproyeksikan untuk membentuk SDM yang siap dengan penciptaan lapangan kerja. Hal ini senada dengan penelitian (Ngadi 2014) yang mengungkapkan adanya relevansi antara kompetensi pendidikan kejuruan dengan pasar dunia kerja.

Penelitian yang dilakukan oleh (Alam 2016) juga mengungkapkan bahwa tingkat pengangguran di Indonesia telah banyak terserap oleh lapangan kerja yang diciptakan oleh lulusan Sekolah Kejuruan. Hal ini menunjukkan bahwa kompetensi lulusan SMK telah banyak membantu dalam pengurangan pengangguran. Di sisi lain dalam penelitian ini juga diungkapkan bahwa melanjutkan ke jenjang Perguruan Tinggi belum menjamin kesuksesan dalam meraih pekerjaan. Namun dengan kompetensi yang dibangun siswa/i SMK selama belajar di bangku kuliah mampu membantu mereka dalam membuka lapangan kerja. Minimal ada harapan mereka bisa bersaing dalam dunia kerja.

Salah satu kompetensi yang diajarkan selama di bangku Sekolah Kejuruan adalah penguasaan Aplikasi Microsoft Office. MS-Word adalah aplikasi office yang paling sering digunakan (Setiawan, Hamzah, and Arlenny 2019). Fitur MS-Word memungkinkan tenaga administrasi dan perkantoran dapat bekerja lebih efisien dan produktif. Namun tidak banyak siswa/i Sekolah Kejuruan mampu mengeksplorasi semua fitur tersebut untuk mendukung kinerja. Hal yang sama dilaporkan oleh (Farida, Agustini, and Wathani 2017) yang mengungkapkan adanya ketimpangan kemampuan guru dengan murid dalam penguasaan aplikasi office. Ketimpangan ini disebabkan beberapa faktor salah satunya adalah tidak atau belum mengenal fitur $M S$-Word lebih jauh. Hal ini diungkapkan oleh (Sari, Fitriyani, and Prabandari 2020) dalam penelitiannya bahwa penggunaan MS-Office khususnya MS-Word dan Excel kurang optimal karena beberapa fitur tersembunyi belum tereksplorasi.

Optimalisasi fitur $M S$-Word terhadap siswa/i Sekolah Kejuruan juga pernah dilakukan oleh (Dharmawati 2020), di mana dalam kegiatannya mengungkapkan adanya peningkatan kompetensi penguasaan Aplikasi Office oleh siswa SMK. Hal ini mengingat penguasaan aplikasi tersebut untuk mendukung kerja keadministrasian menjadi keniscayaan (Kelen et al. 2020). SMK Dharma Siswa 2 Sidoarjo adalah salah satu Lembaga Pendidikan menengah yang menyelenggarakan Pendidikan kejuruan. Kompetensi penguasaan aplikasi office menjadi salah satu kompetensi unggulan jurusan Administrasi Perkantoran. Kegiatan Program Kemitraan Masyarakat ini bertujuan untuk meningkatkan kompetensi tersebut.

Permasalahan yang sedang dihadapi oleh SMK Dharma Siswa 2 Sidoarjo ini adalah terkait dengan penguasaan aplikasi office khususnya $M S$-Word. Kurang optimalnya penguasaan ini selain kurangnya tenaga pengajar yang mempunyai kompetensi Aplikasi Office yang tersertifikasi, berakibat pada kurang optimalnya juga kompetensi yang dimiliki siswa. Secara jangka Panjang, maka lulusan SMK Dharma Siswa 2 Sidoarjo kurang/tidak dapat bersaing dengan lulusan Sekolah Kejuruan lain yang sejenis. Hal ini juga dapat berisiko menurunnya daya saing SMK Dharma Siswa 2 Sidoarjo di mata publik. Padahal peningkatan jumlah siswa SMK dapat membantu peningkatan pembangunan ekonomi (Slamet 2017). Jika hal tersebut berlarut, maka SMK tersebut 
dapat kehilangan kesempatan untuk berpartisipasi dalam pembangunan ekonomi, terutama ekonomi daerah.

Berdasarkan permasalahan di atas, kegiatan PKM ini bertujuan untuk meningkatkan kompetensi siswa SMK Dharma Siswa 2 Sidoarjo dalam penguasaan aplikasi office khususnya MS-Word. Penguasaan ini terkait dengan literasi fitur tersembunyi $M S$-Word untuk mendukung kinerja manajemen naskah. Hal ini juga sangat bermanfaat untuk membantu efisiensi dalam pembuatan naskah laporan dan artikel ilmiah.

\section{METODE PENGABDIAN MASYARAKAT}

Metode yang digunakan dalam kegiatan pengabdian ini adalah pelatihan dan pendampingan dan pelatihan. Pelatihan ini terkait dengan literasi fitur referen $M S$-Word untuk meningkatkan efisiensi pembuatan naskah laporan dan artikel ilmiah. Pendampingan dilakukan terhadap siswa SMK Dharma Siswa 2 Sidoarjo pada setiap praktikum untuk memastikan ada peningkatan kompetensi peserta. Pengukurannya dilakukan dengan membandingkan pra atau sebelum pelatihan dan sesudah pelatihan. Indikator menggunakan tes pre-requisites dan pos-tes terkait materi yang diberikan. Berikut ini adalah metode dan tahapan kegiatan PKM.

Tabel 1 Rencana Kegiatan dan Hasil

\begin{tabular}{lll}
\hline No. & Rencana Kegiatan & Indikator dan Hasil \\
\hline 1. & Perencanaan Teknis Kegiatan & Desain Kegiatan Pelatihan \\
\hline 2. & Pembuatan Modul Pelatihan & Tersedia satu modul pelatihan \\
\hline 3. & $\begin{array}{l}\text { Pelatihan pemanfaatan Referen pada } M S- \\
\text { Office }\end{array}$ & $\begin{array}{l}\text { Mitra memahami dan menerapkan } \\
\text { hasil pelatihan penggunaan referen } \\
\text { pada } M S \text {-Office }\end{array}$ \\
\hline 4. & Pelatihan penyusunan indeks dalam naskah & $\begin{array}{l}\text { Mitra memahami dan menerapkan } \\
\text { hasil pelatihan penyusunan indeks } \\
\text { laporan }\end{array}$ \\
&
\end{tabular}

\section{HASIL DAN PEMBAHASAN}

Merujuk pada analisis situasi, dapat disimpulkan bahwa SMK Dharma Siswa 2 Sidoarjo membutuhkan literasi MS-Office khususnya MS-Word untuk meningkatkan kompetensinya. Pelatihan pemanfaatan fungsi referen ini dibagi menjadi tiga bagian yaitu Table of Content (ToC), insert reference dan index, serta terakhir adalah insert figure, table, caption, dan equation for indexing.

\section{Bagian 1 Table of Content (ToC)}

Pada bagian ini dimulai dengan melakukan pre-requisite test terkait dengan materi yang akan disampaikan. Tes ini dilakukan untuk mengukur atau memetakan kondisi pengetahuan siswa. Pengetahuan ini terkait dengan kemampuan dan literasi siswa tentang fungsi ToC dalam sebuah naskah laporan. Table hasil pre-requisites test bisa dilihat di bawah ini: 


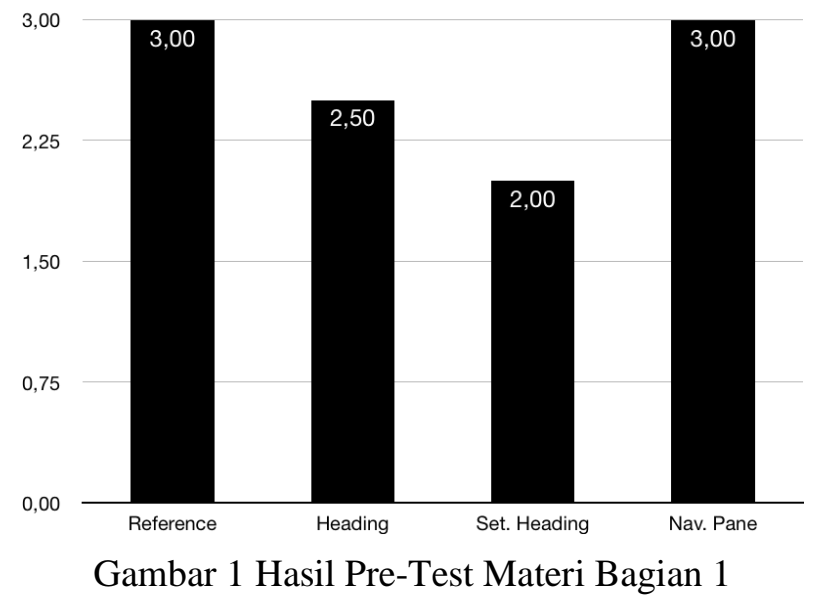

Berdasarkan hasil tes materi bagian pertama dari skala 1 - 10, rata-rata peserta hanya berada pada level 2 -3. Hal ini menunjukkan tingkat pemahaman terhadap fitur ToC masih rendah. Maka pada bagian pertama ini, materi akan diberikan seputar tahapan pembuatan ToC dengan benar. Bagian ini pada dasarnya mengenalkan siswa cara pembuatan Daftar Isi pada sebuah naskah yang panjang. Asumsi pertama digunakan pada proses awal pembuatan naskah. Asumsi kedua adalah sudah ada naskah panjang dan membutuhkan indeks dan daftar isi. Pengenalan awal yang dilakukan adalah dengan pembuatan heading dan navigation pane. Fitur ini digunakan sebagai panduan atau navigasi dalam penulisan naskah. Kemampuan menguasai materi ini sangat bermanfaat dalam meningkatkan kecepatan proses pembuatan laporan dan atau artikel ilmiah. Hal ini terlihat dari kemampuan siswa untuk berpindah (mengakses) dari sub pokok bahasan satu ke bahasan lainnya dalam naskah yang panjang. Navigation pane ini juga merupakan bentuk miniatur dari Table of Content $(T o C)$. Materi pada bagian ini meliputi sebagai berikut:

Tabel 2 Materi Bagian 1

\begin{tabular}{ll}
\hline Nama Kegiatan & Materi \\
\hline Tab Reference & Dasar-Dasar Tab Reference \\
& 1. Fungsi Tab Reference \\
\hline Tab Heading & 2. Fitur tab reference \\
& $\begin{array}{l}\text { Dasar-dasar tab heading } \\
\text { 1. Fungsi Tab heading } \\
\text { 2. Fitur dalam tab heading }\end{array}$ \\
\hline Netting Heading & 1. Membuat Title \\
& 2. Membuat subtitle \\
& 3. Heading \\
& 4. Setting and modify heading \& Title \\
& Dasar-Dasar Navigation Pane \\
& 2. Menampilkan navigation pane \\
& 3. Search index menggunakan navigation pane \\
\hline
\end{tabular}

Peserta diberikan post-test Ketika selesai materi bagian pertama. Post-test ini bertujuan untuk membandingkan kondisi sebelum dan setelah diberikan pelatihan. Grafik di bawah ini menunjukkan kondisi post-test pasca pemberian materi. 


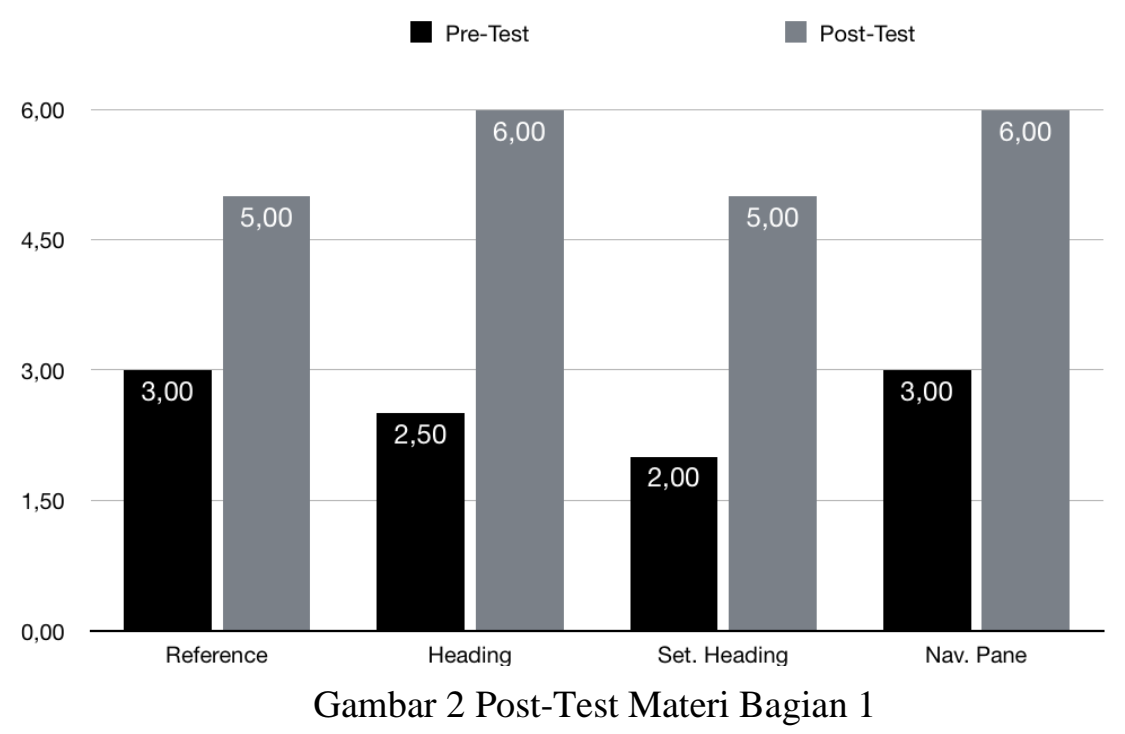

Berdasarkan grafik post-test bagian 1 di menunjukkan kenaikan yang cukup signifikan. Prosentase kenaikan literasi materi bagian 1 ini mencapai 100\%. Namun jika ditinjau dari skala $1-10$ level literasi masih berada pada level 5 . Hal ini wajar mengingat pelatihan ini hanya dilakukan dalam tempo singkat.

\section{Bagian 2 Inserting Reference \& Bibliography}

Pre-Test pada bagian ini cukup menggembirakan jika melihat skala hasilnya. Hal test dari skala 1 - 10, peserta berada pada level rata-rata 4. Hal ini menunjukkan, bahwa pengetahuan dan literasi inserting bibliography pada naskah cukup bagus. Grafik di bawah ini menunjukkan kondisi hasil tes sebelum diberikan materi pelatihan.

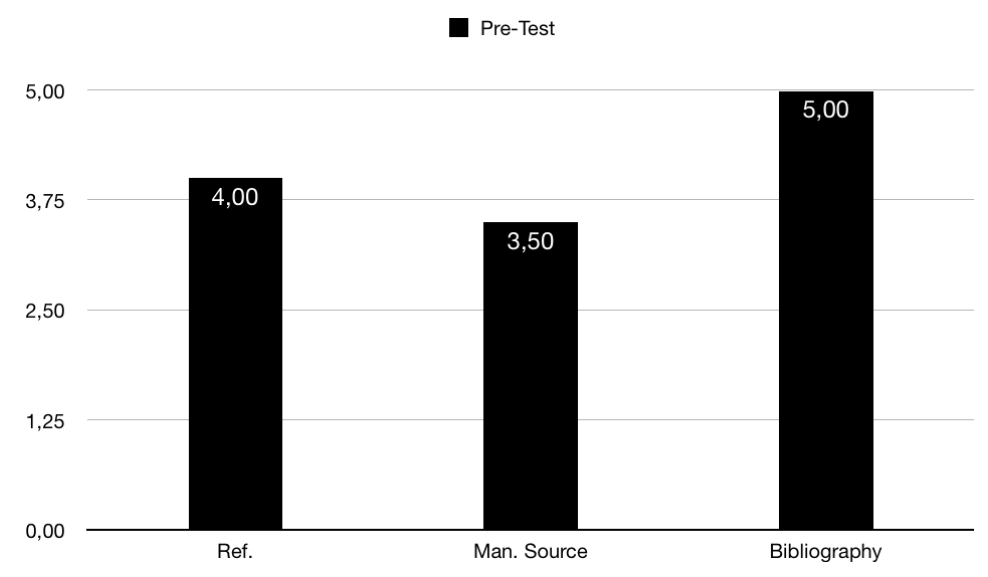

Gambar 3 Pre-Test Materi Bagian 2

Bagian ini memperkenalkan fungsi dan cara menggunakan fitur reference dan bibliography. Fitur ini bermanfaat ketika membuat naskah yang membutuhkan sitasi atau kutipan. Pembuatan kutipan ini juga akan menjadi rumit jika tenaga administrasi kesekretariatan tidak/kurang memahami tools tersebut. Materi ini juga mendemokan bagaimana cara membuat daftar pustaka secara otomatis. Selain itu, materi ini juga memperkenalkan model style sitasi. Beberapa model sitasi yang diperkenalkan adalah : APA; $6^{\text {th }}$ ed.; Chicago; $6^{\text {th }} e d$.; GB7714; 2005; GHOST-Name Sort; 2003; GHOST - Title Sort; 2003; Harvard - Anglia; 2008; IEEE; 2006; ISO 690 - First Element and Date; 1987; ISO 690 - Numerical Reference; 1987; MLA; $7^{\text {th }}$ ed.; SIST02; 2003; Turabian; $6^{\text {th }}$ ed. 
Pada bagian ini secara khusus menggunakan style APA version $6^{\text {th }}$ edition. Pertimbangannya adalah, style ini adalah yang paling umum digunakan. Style lain bukan berarti kurang baik, namun tidak atau kurang populer digunakan.

Materi pada bagian ini meliputi hal sebagai berikut:

1. Tab reference.

2. Manage source.

3. Bibliography

Bagian ini berfokus pada pengenalan tab reference untuk proses pembuatan sitasi. Salah satu proses awal yang cukup menyita waktu adalah membangun database source (sumber) referen. Salah satu kunci keberhasilan pada proses ini adalah entri data sumber referensi dengan disiplin dan konsisten. Pilihan style yang digunakan adalah APA. Rincian tahap ini adalah sebagai berikut:

Tabel 3 Materi Bagian 2

\begin{tabular}{ll}
\hline Nama Kegiatan & Materi \\
\hline Tab Reference & 1. Dasar-dasar tab reference \\
& 2. Fungsi tab reference \\
& 3. Fitur tab \\
& 4. Mengatur tab \\
\hline Manage Source & 1. Memasukkan data referensi \\
& 2. Edit data referensi \\
& 3. Memilih form masukan referensi yang sesuai \\
\hline Bibliography & 1. Insert data bibliografi \\
& 2. Update field data bibliography \\
& 3. Menempatkan bibliography sesuai halaman yang diinginkan \\
\hline
\end{tabular}

Seperti pada bagian sebelumnya, setelah mengikuti materi bagian kedua, peserta menjalani posttest. Hasil post-test setelah mendapatkan materi pelatihan cukup menggembirakan. Peningkatan literasi dan kemampuan peserta pada materi bagian 2 ini meningkat cukup signifikan. Grafik peningkatan literasi dan kemampuan peserta pada materi bagian 2 dapat dilihat di bawah ini:

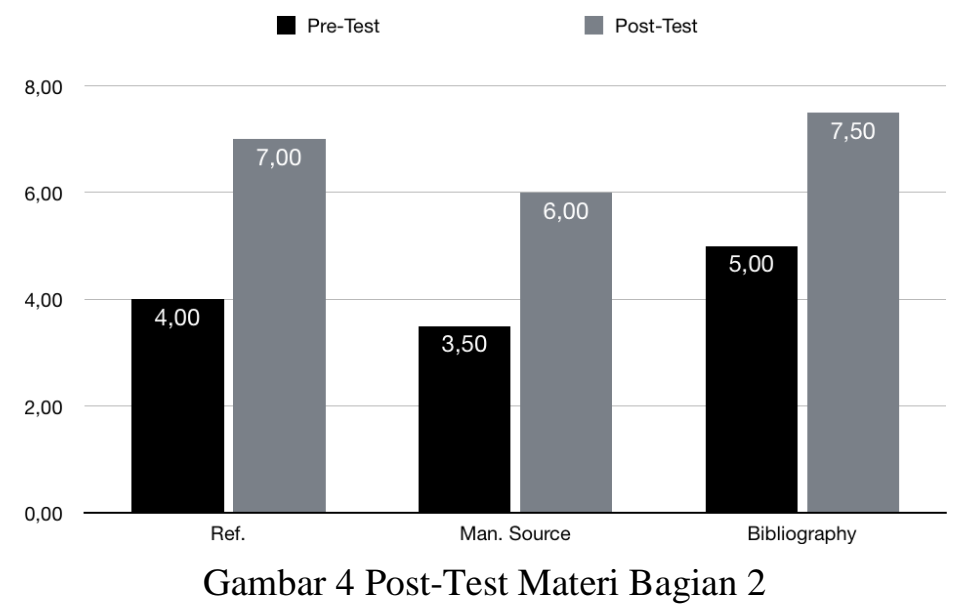

Berdasarkan grafik di atas menunjukkan bahwa ada peningkatan yang cukup signifikan. Pada sesi ini semua peserta menyerap materi dengan baik, dan tidak ada materi yang kurang terserap. Hal ini ditunjukkan dengan prosentasi peningkatan rata-rata $50 \%$ pada semua materi bagian 2 . Jika dilihat dari $1-10$, literasi dan kemampuan peserta setelah mendapatkan materi berada pada level 7. 


\section{Bagian 3 Insert Figure, Table, \& Equation for Indexing}

Pembuatan caption (keterangan) pada setiap ilustrasi (gambar), rumus, tabel, dan lain-lain tidak kalah penting dalam pembuatan laporan. Fitur ini berfungsi untuk membuat daftar tabel, gambar, rumus, dan lain sebagainya. Hasil pre-test peserta pada materi ini cukup rendah. Hal ini wajar, mengingat proses penggunaan fitur ini membutuhkan effort yang keras. Grafik di bawah ini menunjukkan hasil pre-test materi bagian 3 .

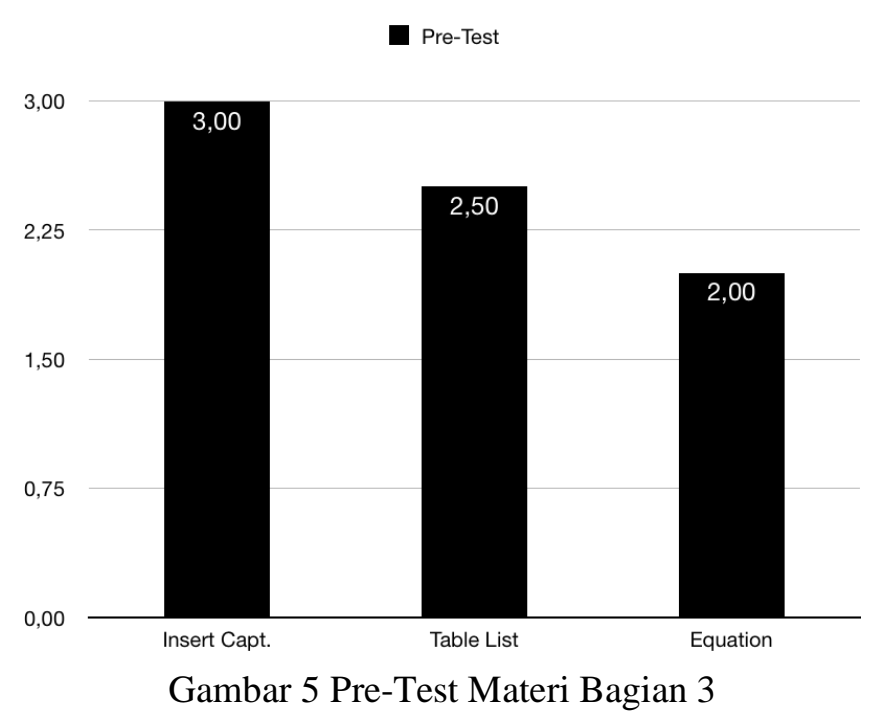

Berdasarkan hasil tes awal literasi dan kemampuan materi bagian 3, kemampuan peserta masih sangat rendah. Dari skala 1 - 10, rerata masih di level 2,5. Materi pada bagian 3 ini meliputi Teknik menyisipkan keterangan (caption), membuat daftar tabel, dan menyisipkan rumus. Khusus pada materi penyisipan rumus, Sebagian peserta training tidak/belum paham betul bagaimana cara menggunakan fitur tersebut. Proses pembuatannya sama dengan membuat reference. Namun yang membedakan adalah proses ini merujuk pada ilustrasi, tabel, rumus, dan sejenisnya. Rincian materi pada bagian atau sesi ini bisa dilihat pada tabel di bawah ini:

Tabel 4 Materi Bagian 3

\begin{tabular}{ll}
\hline Nama Kegiatan & Materi \\
\hline Insert Caption & 1. Dasar-dasar caption \\
& 2. Fungsi caption \\
\hline Table List & 3. Cara inserts caption \\
& 1. Membuat daftar tabel \\
& 2. Mengatur caption table \\
\hline Equation & 3. Add new table name \\
& 1. Dasar-dasar equation \\
& 2. Insert equation. \\
& 3. Edit equation. \\
& 4. Insert equation list \\
\hline
\end{tabular}


Materi tersebut adalah dasar dari penyisipan caption, daftar keterangan, dan rumus. Penggunaan fitur ini bermanfaat untuk pembuatan naskah laporan atau artikel ilmiah yang membutuhkan banyak sisipan rumus-rumus beserta table. Post-test materi ini menunjukkan peningkatan yang cukup baik meskipun tidak sebaik peningkatan pada materi sebelumnya. Hal ini karena tingkat kesulitan materi ini cukup tinggi terutama pada sesi materi equation. Grafik peningkatan literasi dan kemampuan peserta dapat dilihat di bawah ini.

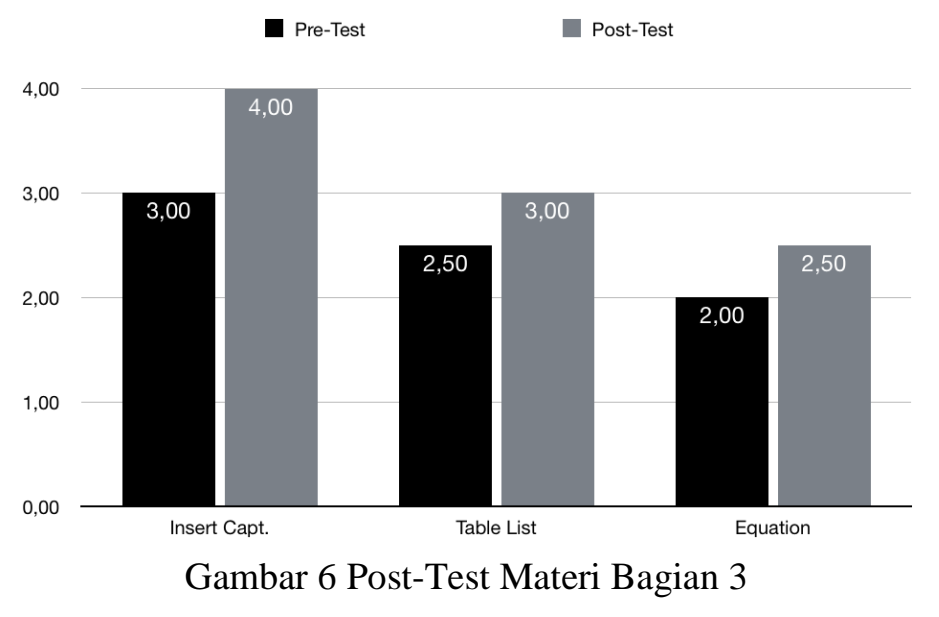

Meskipun peningkatan kemampuan pada materi bagian 3 ini tidak cukup signifikan, namun tetap ada perubahan. Paling tidak dari seluruh materi yang terserap, ada kontribusi $25 \%$ peningkatan kemampuan. Jika di rata-rata perbedaan perbandingan kemampuan sebelum dan sesudah mendapatkan training adalah sebagai berikut:

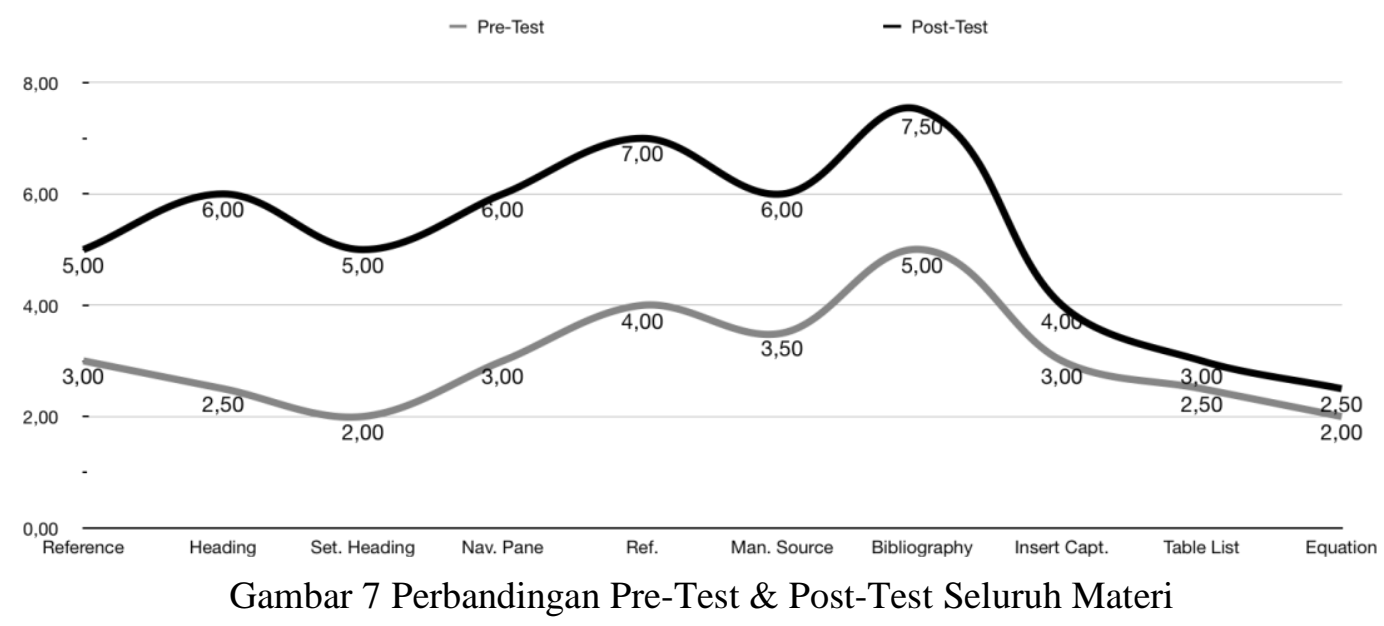

Perubahan peningkatan dari setiap materi maupun bagian rerata mencapai 50\% dari level semula. Namun khusus untuk materi equation, peningkatan literasi dan kemampuan menggunakan fitur tersebut tidak/kurang signifikan. Hal ini disebabkan karena tingkat kerumitan proses penggunaan fitur ini cukup tinggi. 


\section{PENUTUP}

Berdasarkan kegiatan PKM tersebut di atas pada Sekolah Menengah Kejuruan SMK Dharma Siswa 2 Sidoarjo telah berjalan dengan baik. Hasil pelatihan terkait pemanfaatan fungsi reference untuk efisiensi manajemen naskah laporan dan pembuatan artikel ilmiah menunjukkan hal positif. Ada peningkatan cukup menggembirakan jika dibandingkan dengan sebelum dilakukan pelatihan. Peningkatan terbesar terkait dengan penggunaan heading dan cara mengaturnya (setting). Hal ini terlihat dari hasil peningkatan level pengetahuan dari level 2 naik menjadi level 6 dari skala 10. Begitu juga dengan literasi materi lainnya, ada peningkatan cukup signifikan. Hal ini terlihat dari literasi penggunaan reference dan fitur navigasi naskah yang naik ke level 7 dari level 4 pada skala 10. Salah satu kendala yang dihadapi dalam kegiatan pelatihan ini adalah tidak meratanya versi aplikasi office yang dimiliki peserta. Kegiatan ini mensyaratkan aplikasi yang digunakan pada versi minimal 2013 ke atas. Namun beberapa peserta masih menggunakan versi 2007, bahkan ada yang masih menggunakan versi 2003.

Beberapa saran yang bisa diberikan pada kegiatan ini antara lain adalah: 1) keberlanjutan proses belajar dan pemberian materi. Hal ini mengingat kompetensi ini akan terus digunakan oleh siswa/i ketika memasuki dunia kerja. 2) pemberian materi pelatihan integrasi office (collaboration) untuk lebih efisiensi dalam mengelola dokumen atau naskah laporan kerja.

\section{UCAPAN TERIMA KASIH}

Kegiatan ini dapat berjalan lancar berkat kontribusi semua pihak yang terlibat langsung maupun tidak langsung. Beberapa pihak yang berkontribusi tersebut adalah:

1. Universitas Dinamika atas dukungan perijinan dan penugasan selama kegiatan ini berlangsung

2. Bagian PPM Universitas Dinamika atas dukungan perijinan dan komunikasi dengan mitra PKM.

3. Kepala Sekolah, Guru, dan tenaga administrasi lainnya di SMK Dharma Siswa 2 Sidoarjo atas kesediaannya sebagai mitra.

4. Mahasiswa Universitas Dinamika (Tim Pelatihan) yang membantu menjadi asisten pemateri selama pelatihan berlangsung.

\section{DAFTAR PUSTAKA}

Alam, Syamsul. 2016. "Tingkat Pendidikan Dan Pengangguran Di Indonesia (Telaah Serapan Tenaga Kerja SMA/SMK Dan Sarjana).” Jurnal Imiah BONGAYA (Manajemen \& Akuntansi) (XIX): 250-57.

Dharmawati, Dharmawati. 2020. "Pembelajaran Berbasis Komputer Menggunakan Ms. Office 2019 Pada Siswa Di Smk Dwitunggal 1 Tanjung Morawa.” Dinamisia : Jurnal Pengabdian Kepada Masyarakat 4(1).

Farida, Muthia, Dian Agustini, and Muhammad Rais Wathani. 2017. "Pemanfaatan Microsoft Word Dalam Pembuatan Karya Ilmiah Bagi Guru Di Mts. Al-Furqon Banjarmasin.” Jurnal Al-Ikhlas 2(2): 20-22.

Kelen, Yosep PK. et al. 2020. "Pelatihan Penggunaan Microsoft Office Bagi Siswa SMPS St. 
Yosef Maubesi." JATI EMAS (Jurnal Aplikasi Teknik dan Pengabdian Masyarakat) 4(2): 85.

Ngadi. 2014. "The Relevance of Vocational Education on Labor Market in Salatiga." Jurnal Kependudukan Indonesia 9(1): 59-70.

Perdana, Novrian Satria. 2019. "Analisis Permintaan Dan Penawaran Lulusan SMK Dalam Pemenuhan Pasar Tenaga Kerja.” Jurnal Ilmiah Kependidikan 9(2): 172-81.

Salam, Abdus, and Taufiq Iqbal. 2020. "IbM Pelatihan Microsoft Office Dalam Rangka Membentuk Masyarakat Yang Profesional.” Jurnal Pengabdian Nasional (JPN) Indonesia 1(1): 10-15.

Sari, Rafika, Aida Fitriyani, and Rosiana Disiati Prabandari. 2020. "Optimalisasi Penggunaan MS. Word Dan MS. Excel Pada Siswa SMP PGRI Astra Insani Bekasi." Jurnal Pengabdian kepada Masyarakat UBJ 3(2): 95-104.

Setiawan, David, Hamzah Hamzah, and Arlenny Arlenny. 2019. "Pelatihan Ms.Word \& Mendeley Untuk Penulisan Karya Ilmiah Dosen Fakultas Teknik Unilak." Dinamisia: Jurnal Pengabdian Kepada Masyarakat 3(1): 172-79.

Slamet. 2017. "The Contribution of Policy of Increasing the Number." Journal UNY 15(3): 30111.

Sormin, Masdelima Azizah, Nur Sahara, and Lisna Agustina. 2018. "Pelatihan Pemanfaatan Perangkat Lunak (Microsoft Office Word, Excel, Power Point) Dalam Kinerja Pengolahan Data Di Pemerintahan Desa Bagikepala Desa Se-Kecamatan Batang Angkola." Martabe: Jurnal Pengabdian Kepada Masyarakat 1(2): 78.

Valentina, Rossa, Maisyaroh Maisyaroh, and Desi Eri Kusumaningrum. 2018. "Hubungan Kompetensi Dan Motivasi Kerja Dengan Kinerja Tenaga Administrasi Sekolah.” Jurnal Administrasi dan Manajemen Pendidikan 1(1): 79-86. 